\title{
Effects of Trapidil and Suramin on Growth Factor-induced Calcium Response and Tyrosine Phosphorylation in Human Glioma Cells
}

\author{
Kazuhiko BANDo, Seiji KANNUKI, Kazuhito ROKUTAN*, \\ Masayuki SHOUNO**, and Keizo MATSUMOTO
}

\begin{abstract}
Departments of Neurosurgery and ${ }^{*}$ Nutrition, and ${ }^{* *}$ General Laboratory of Medical Research, School of Medicine, The University of Tokushima, Tokushima
\end{abstract}

\begin{abstract}
Platelet-derived growth factor (PDGF) and epidermal growth factor (EGF) induce the proliferation of glioma cells in vitro. Trapidil and suramin inhibit this growth factor-stimulated glioma cell growth, but the mechanisms are not fully understood. The effects of trapidil and suramin on PDGF- and EGFinduced early biochemical events in T98G cells were studied. PDGF induced a rapid increase of intracellular free calcium concentration $\left(\left[\mathrm{Ca}^{2+}\right] \mathrm{i}\right)$ in fura-2/acetoxymethyl ester-loaded single glioma (T98G) cells. This increase was completely inhibited by removal of extracellular $\mathrm{Ca}^{2+}$ with ethylene glycol bis $(\beta$-aminoethyl ether)-N,N,N,N-tetraacetic acid but not by an L-type calcium channel blocker (nicardipine), suggesting that PDGF may cause calcium influx through voltage-independent calcium channels in T98G cells. Trapidil and suramin blocked the PDGF-induced calcium response and inhibited the PDGF-initiated tyrosine phosphorylation of the PDGF receptor as detected by Western blot analysis using an antibody specific for phosphotyrosine. Trapidil and suramin also inhibited EGF-initiated calcium response in T98G cells, but only partially inhibited EGF-initiated tyrosine phosphorylation at the same concentrations. Our results suggest that trapidil and suramin inhibit PDGF- and EGF-initiated early biochemical events, and thus suppress growth factor-induced cell proliferation.
\end{abstract}

Key words: growth factor, calcium response, tyrosine phosphorylation, trapidil, suramin

\section{Introduction}

Growth factors may stimulate tumor growth through the autocrine or paracrine mechanisms. Plateletderived growth factor (PDGF) and transforming growth factor- $\alpha$ (TGF- $\alpha$ ) are produced by glioma cells, ${ }^{16,21)}$ and their autocrine loops may be important for the proliferation of glioma cells. PDGF and epidermal growth factor (EGF) promote the proliferation of glioma cells in vitro, ${ }^{24,25)}$ and exert their biological actions through activation of the receptor kinases, promoting many cellular alterations including the generation of signals that activate transcription and the tyrosine phosphorylation of specific intracellular substrates. ${ }^{3,20)}$ Although the mitogen-initiated signals that trigger replication are not well understood, inhibitors that block one (or more) mitogen signals may inhibit the proliferation of tumor cells and may be clinically useful for the control of tumor growth.

Trapidil is a potent coronary vasodilator with an anti-aggregating effect, ${ }^{22)}$ and inhibits PDGFstimulated cell proliferation, ${ }^{17,23,30)}$ possibly acting as a competitive antagonist at the PDGF receptor. ${ }^{23)}$ Suramin, a polyanionic compound and an antiparasitic agent used for treating African trypanosomiasis and onchocerciasis, inhibits the reverse transcriptase activity of ribonucleic acid tumor viruses or mammalian deoxyribonucleic acid polymerase. ${ }^{6,19,27)}$ In addition, suramin may block the binding of growth factors to their receptors and subsequently inhibit proliferation of various types of

Received November 4, 1994; Accepted January 27, 1995

Author's present address: K. Bando, M.D., Department of Neurosurgery, Oita Nakamura Hospital, Oita, Japan. 
cells. ${ }^{1,8,33)}$ However, the mechanisms of these agents are not fully understood.

This study investigated the effects of trapidil and suramin on PDGF- and EGF-induced early biochemical events in a glioma cell line (T98G) established from human glioblastoma, ${ }^{28)}$ using a single cell technique to detect mitogen-induced calcium response, and Western blot analysis to detect proteins containing phosphorylated tyrosine.

\section{Materials and Methods}

\section{Cell culture}

Human glioblastoma cells (T98G; American Type Culture Collection, Rockville, Md., U.S.A. ${ }^{28}$ ) were grown in Dulbecco's minimum essential medium (DMEM) supplemented with $10 \%$ fetal bovine serum (FBS) (Flow Laboratories, McLean, Va., U.S.A.), $1 \%$ sodium pyruvate, $1 \%$ non-essential amino acids (Nissui Pharmaceutical Co., Tokyo), $100 \mathrm{IU} / \mathrm{ml}$ penicillin $\mathrm{G}, 100 \mu \mathrm{g} / \mathrm{ml}$ streptomycin, and $250 \mu \mathrm{g} / \mathrm{ml}$ amphotericin $\mathrm{B}$ under $5 \% \mathrm{CO}_{2}-95 \%$ air at $37^{\circ} \mathrm{C}$.

\section{Mitogen-induced calcium response}

T98G cells in the exponential growth phase were subcultured on a glass coverslip in a $35-\mathrm{mm}$ diameter culture dish at $2.5 \times 10^{3}$ cells $/ \mathrm{ml}$ in culture medium under $5 \% \mathrm{CO}_{2}-95 \%$ air at $37^{\circ} \mathrm{C}$. Cells on a coverslip were washed three times with DMEM and then serum-starved for 6 hours by incubating with culture medium lacking FBS. The cells were loaded with 2.5 $\mu \mathrm{M}$ fura-2/acetoxymethyl ester (Dojin Chemical Co., Tokyo) in serum-free DMEM containing 5\% bovine serum albumin (fraction V; Miles Inc., Kankakee, Ill., U.S.A.) at $37^{\circ} \mathrm{C}$ for 30 minutes and washed three times with Hank's balanced salt solution without phenol red (HBSS) (Nissui Pharmaceutical Co.). The cells attached to the coverslip were placed in a bath (volume $0.5 \mathrm{ml}$ ) on the stage of a fluorescence microscope (Optiphoto; Nikon, Tokyo) equipped with a photomultiplier tube (R649; Hamamatsu Electronics, Shizuoka), a photon counter (545A; NF, Hiroshima), and an appropriate combination of filters (Nihon Shinkuu Kougaku, Osaka). Alternating excitation was repeated with wavelengths of $340\left(F_{340}\right)$ and $380 \mathrm{~nm}\left(F_{380}\right)$. Ratio values $\left(F_{340} / F_{380}\right)$ were converted to cytosolic free calcium concentration $\left(\left[\mathrm{Ca}^{2+}\right] \mathrm{i}\right)$ by a calibration curve based on the fluorescence of acid-free fura- 2 solution. ${ }^{15)}$ As previously reported, the ratio of $\mathrm{F}_{340} /$ $F_{380}$ was linear with $\log \left[\mathrm{Ca}^{2+}\right] \mathrm{i}$ over a wide range of $80-1000 \mathrm{nM}^{31)}\left[\mathrm{Ca}^{2+}\right] \mathrm{i}$ was calculated using a personal computer. $\mathrm{HBSS}$ at $37^{\circ} \mathrm{C}$ was continuously circulated at $1 \mathrm{ml} / \mathrm{min}$. Cells on the coverslip were ex- posed to the various concentrations of recombinant human PDGF (R\&D Systems Inc., Minneapolis, Minn., U.S.A.) or EGF (Higeta Shoyu Co., Chiba), FBS, or inhibitors at $37^{\circ} \mathrm{C}$ using circulation medium (HBSS) containing each agent as follows. All experiments were performed in triplicate.

PDGF-induced calcium response was examined by stimulating cells with $10 \mathrm{ng} / \mathrm{ml}$ PDGF. Extracellular calcium was then removed by circulating HBSS with $2.26 \mathrm{mM}$ ethylene glycol bis( $\beta$-aminoethyl ether)$\mathrm{N}, \mathrm{N}, \mathrm{N}, \mathrm{N}$-tetraacetic acid (EGTA) (Dojin Chemical Co.), and cells were stimulated with $10 \mathrm{ng} / \mathrm{ml}$ PDGF. Cells were pretreated with $10 \mu \mathrm{M}$ nicardipine (Yamanouchi Pharmaceutical Co., Tokyo) for 6 hours in serum-free DMEM in the $\mathrm{CO}_{2}$ incubator at $37^{\circ} \mathrm{C}$, and then stimulated by $10 \mathrm{ng} / \mathrm{ml}$ PDGF. After stimulation by PDGF, the circulating medium was changed to HBSS containing $10 \%$ FBS as a positive control.

The effects of trapidil and suramin on PDGF-induced calcium response were examined by pretreatment of cells for 5 minutes with 10 or $100 \mu \mathrm{g} / \mathrm{ml}$ trapidil (Mochida Pharmaceutical Co., Tokyo), or 10 or $100 \mu \mathrm{g} / \mathrm{ml}$ suramin (Bayer AG, WuppertalElberfeld, Germany). The cells were then stimulated by $10 \mathrm{ng} / \mathrm{ml}$ PDGF or $10 \%$ FBS in the HBSS circulation medium containing the same concentration of trapidil or suramin.

The effects of trapidil and suramin on EGF-induced calcium response were studied by pretreatment of cells for 5 minutes with 10 or $100 \mu \mathrm{g} / \mathrm{ml}$ trapidil, or 10 or $100 \mu / \mathrm{ml}$ suramin, followed by stimulation by $100 \mathrm{ng} / \mathrm{ml}$ EGF or $10 \%$ FBS in HBSS circulation medium containing the same concentration of trapidil or suramin.

\section{Protein tyrosine phosphorylation}

T98G cells were cultured at $60-80 \%$ confluence in 35-mm-diameter culture dishes, then the medium was replaced with serum-free DMEM. After serum starvation for 16 hours in the absence or presence of trapidil or suramin, cells were treated with $10 \mathrm{ng} / \mathrm{ml}$ PDGF or $100 \mathrm{ng} / \mathrm{ml}$ EGF. The stimulation was terminated at various times by immediately aspirating the medium and adding a previously boiled electrophoresis sample buffer ( $100 \mu \mathrm{l} /$ plate) consisting of $5 \mathrm{mM}$ potassium phosphate $(\mathrm{pH} 6.8), 2 \%$ sodium dodecyl sulfate (SDS), $10 \mathrm{mM}$ dithiothreitol, $5 \% 2$ mercaptoethanol, $0.04 \%$ bromophenol blue, and $2 \%$ glycerol. Cell lysates were collected with a rubber policeman, transferred to microcentrifuge tubes, then boiled for 2 minutes. The lysates were passed through a 22-gauge needle several times and then a 27 -gauge needle 20 times. The extracted proteins (40 
$\mu \mathrm{g}$ protein/lane) were separated by SDSpolyacrylamide gel electrophoresis in $10 \%$ polyacrylamide gel and transferred to a polyvinylidine difluoride membrane. After blocking nonspecific binding sites with 4\% milk casein (Block ACE ${ }^{\mathrm{TM}}$; Yukijirushi Co., Sapporo), the membrane was incubated with a monoclonal antibody specific for phosphotyrosine (clone Py54; Oncogene Sci., Uniondale, N.Y., U.S.A.). Bound antibodies were detected by enhanced chemiluminescence (Amersham Japan, Tokyo).

\section{Results}

\section{Mitogen-induced calcium response}

The basal $\left[\mathrm{Ca}^{2+}\right] \mathrm{i}$ in fura-2/acetoxymethyl esterloaded single cells was $193 \pm 11 \mathrm{nM}$ (mean $\pm \mathrm{SD}$, $\mathrm{n}=17$ ). Single cell analyses showed that a substantial proportion of cells $(<23 \%)$ did not have a calcium response to PDGF, EGF, and FBS, and there were no obvious morphological features predicting which cells would be responsive. Therefore, FBS was always used as a positive control for calcium response, and data from cells unresponsive to FBS were omitted. The PDGF-induced increase of $\left[\mathrm{Ca}^{2+}\right] \mathrm{i}$ was $80.0 \pm 90.4 \mathrm{nM}$ (mean $\pm \mathrm{SD}, \mathrm{n}=13$ ). A typical response is shown in Fig. 1A. The PDGFinduced increase of $\left[\mathrm{Ca}^{2+}\right] \mathrm{i}$ was completely blocked when extracellular $\mathrm{Ca}^{2+}$ was removed with EGTA (Fig. 1B), indicating that PDGF evokes extracellular $\mathrm{Ca}^{2+}$ influx across the plasma membrane. However, the L-type calcium channel blocker, nicardipine, had no effect on the $\mathrm{Ca}^{2+}$ influx stimulated by PDGF (Fig. 1C), suggesting that the $\mathrm{Ca}^{2+}$ entry may not be through voltage-dependent calcium channels.

Trapidil at the concentrations of 10 and $100 \mu \mathrm{g} / \mathrm{ml}$ completely inhibited the PDGF-induced increase of $\left[\mathrm{Ca}^{2+}\right] \mathrm{i}$ (Fig. 2A, B), but did not inhibit the FBS
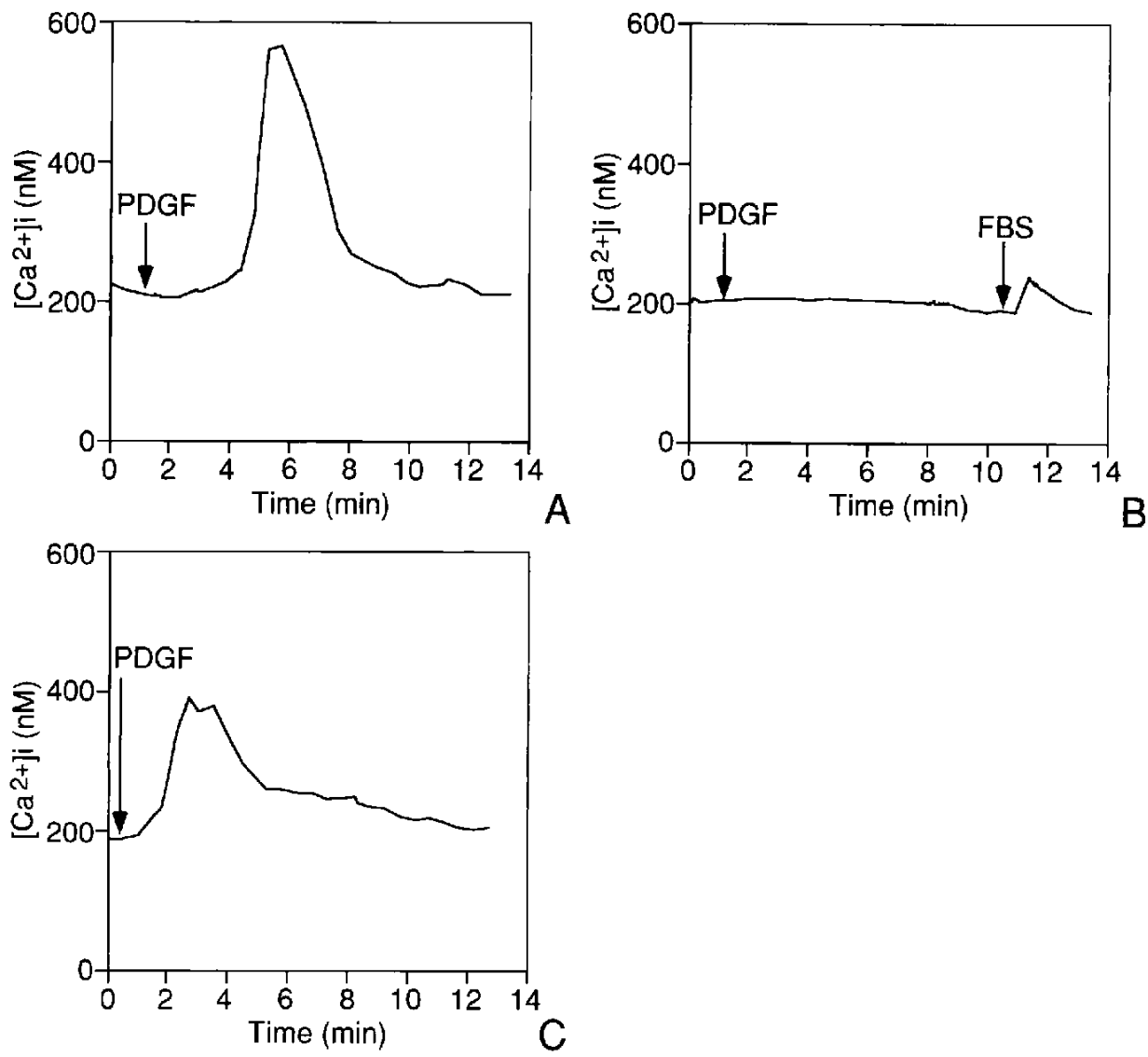

Fig. 1 PDGF-induced calcium response in single T98G cells. A: Typical PDGF-induced increase of $\left[\mathrm{Ca}^{2+}\right]$ i. B: PDGF-induced increase of $\left[\mathrm{Ca}^{2+}\right]$ i was completely blocked by removal of extracellular $\mathrm{Ca}^{2+}$ with EGTA. FBS was used as a positive control for calcium response. C: PDGF-induced $\mathrm{Ca}^{2+}$ response was not affected by nicardipine pretreatment. Results are representative of at least four separate experiments. 

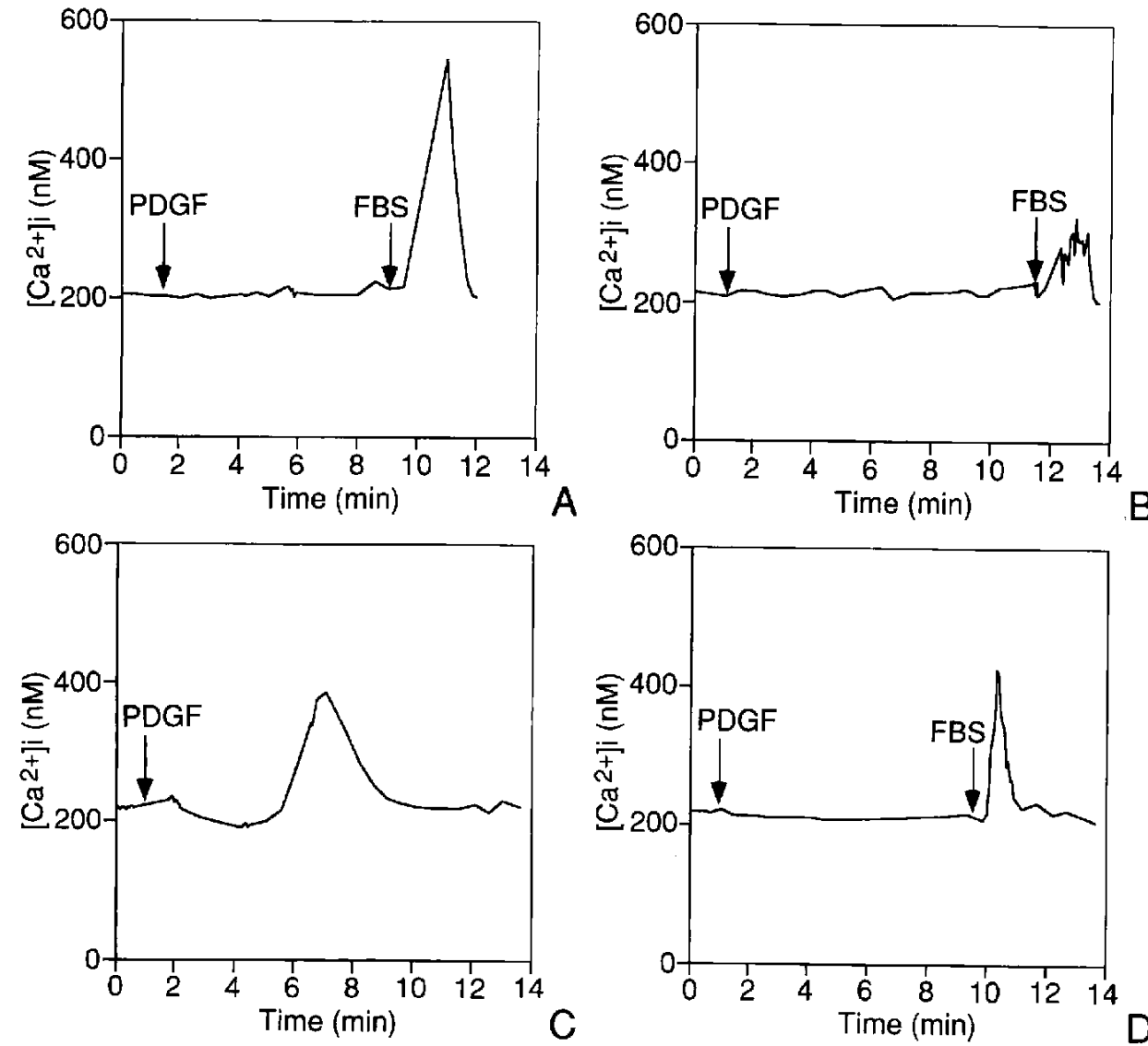

Fig. 2 Effects of trapidil and suramin on PDGF-induced calcium response. Trapidil at 10 (A) and $100 \mu \mathrm{g} /$ $\mathrm{ml}$ (B) completely inhibited the PDGF-induced increase of $\left[\mathrm{Ca}^{2+}\right]$ i. About $25 \%$ of the cells treated with $10 \mu \mathrm{g} / \mathrm{ml}$ suramin (C) demonstrated a calcium response to PDGF. Suramin at $100 \mu \mathrm{g} / \mathrm{ml}$ (D) completely blocked the PDGF-induced $\left[\mathrm{Ca}^{2+}\right] \mathrm{i}$ increase. FBS was used as a positive control for calcium response. Results are representative of four separate experiments.

response. Ten $\mu \mathrm{g} / \mathrm{ml}$ suramin inhibited the PDGF-induced increase of $\left[\mathrm{Ca}^{2+}\right] \mathrm{i}$, but not in all experiments, as about $25 \%$ of the cells treated with $10 \mu \mathrm{g} / \mathrm{ml}$ suramin demonstrated a calcium response to PDGF (Fig. 2C). However, $100 \mu \mathrm{g} / \mathrm{ml}$ suramin completely blocked the PDGF-induced increase of $\left[\mathrm{Ca}^{2+}\right]$ i (Fig. 2D).

EGF caused a calcium response in about $62 \%$ of T98G cells, with an increase in $\left[\mathrm{Ca}^{2+}\right]$ i of $364 \pm 126$ $\mathrm{nM}$ (mean $\pm \mathrm{SD}, \mathrm{n}=13$ ). A typical response is shown in Fig. 3A. Both trapidil and suramin at the concentrations of 10 and $100 \mu \mathrm{g} / \mathrm{ml}$ completely inhibited the EGF-induced increase of $\left[\mathrm{Ca}^{2+}\right] \mathrm{i}$ in the FBS responsive cells (Fig. 3B-E). Therefore, both PDGF- and EGF-induced calcium responses were sensitive to both trapidil and suramin.

\section{Protein tyrosine phosphorylation}

PDGF stimulation of T98G cells caused promi- nent tyrosine phosphorylation of a protein with a molecular mass of $185 \mathrm{kd}$ (Fig. 4, lanes 2 and 3), and probably represents the receptor for PDGF. Pretreatment of the cells with trapidil for $\mathbf{1 6}$ hours inhibited the PDGF-induced tyrosine phosphorylation of this protein (Fig. 4, lanes 4 and 5). Suramin also completely inhibited the PDGF-induced phosphorylation of the $185 \mathrm{kd}$ protein (Fig. 4, lanes 6 and 7). In addition, a protein with molecular mass of $130 \mathrm{kd}$, which already contained phosphotyrosine before addition of PDGF and was not modified with PDGF (Fig. 4, lanes 1-3), showed tyrosine-dephosphorylation with both trapidil and suramin treatment (Fig. 4, lanes 47).

EGF induced rapid tyrosine phosphorylation of the $170 \mathrm{kd}$ protein supposed to be the receptor for EGF and increased the modification of a $76 \mathrm{kd}$ protein (Fig. 5, lanes 2-4), which was weakly tyrosinephosphorylated before addition of EGF (lane 1). 

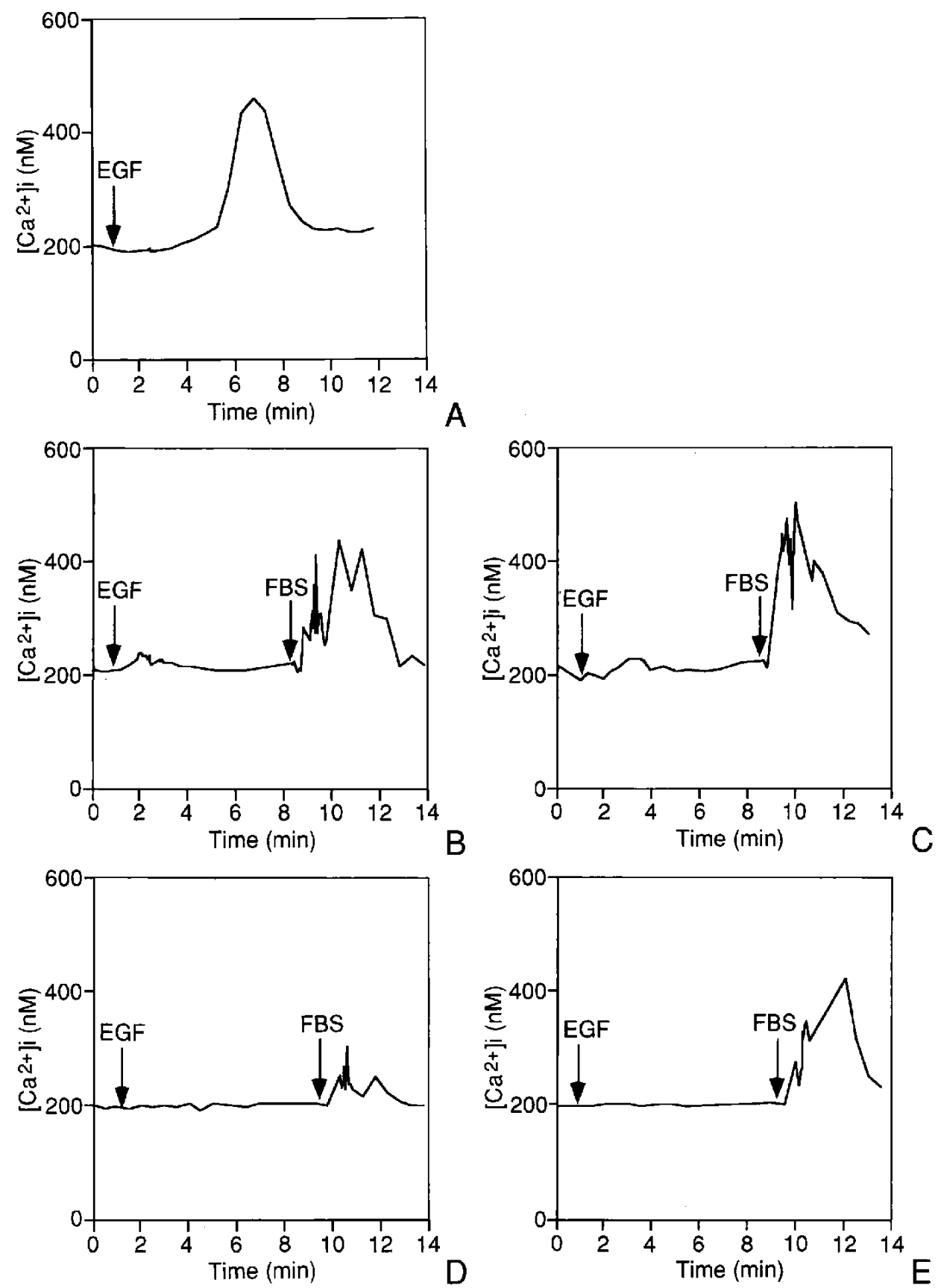

Fig. 3 Effects of trapidil and suramin on EGF-induced calcium response. A: Typical EGF-induced calcium response. Trapidil at 10 (B) and $100 \mu \mathrm{g} / \mathrm{ml}$ (C) and suramin at 10 (D) and $100 \mu \mathrm{g} / \mathrm{ml}$ (E) completely inhibited the EGF-induced increase of $\left[\mathrm{Ca}^{2+}\right] \mathrm{i}$. FBS was used as a positive control for calcium response. Results are representative of four separate experiments.

Pretreatment of cells with trapidil only partially inhibited the EGF-induced tyrosine phosphorylation of 170 and $76 \mathrm{kd}$ proteins (Fig. 5, lanes 5 and 6). This was also the case with suramin (Fig. 5, lanes 7 and 8). The phosphorylation of 170 and $76 \mathrm{kd}$ proteins was only partially decreased with 100 and $200 \mu \mathrm{g} / \mathrm{ml}$ suramin, which completely inhibited the EGF-induced calcium response (Fig. 3). PDGF-induced calcium response and tyrosine phosphorylation were significantly inhibited in the presence of trapidil or 


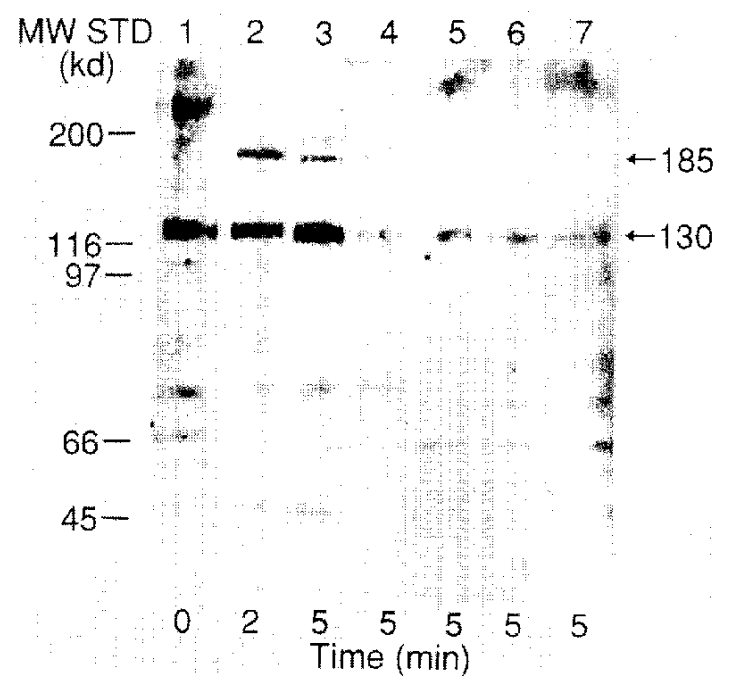

Fig. 4 Effects of trapidil and suramin on PDGF-induced protein tyrosine phosphorylation. Cell proteins were extracted before (lane 1), and 2 (lane 2) and 5 minutes (lane 3) after $10 \mathrm{ng} / \mathrm{ml}$ PDGF stimulation, and 5 minutes after stimulation from cells pretreated with 50 (lane 4) and $100 \mu \mathrm{g} / \mathrm{ml}$ trapidil (lane 5) or 100 (lane 6) and $200 \mu \mathrm{g} / \mathrm{ml}$ suramin (lane 7). Arrows indicate molecular masses calculated from the positions of molecular weight standards (MW STD). Similar results were obtained in three separate experiments.

suramin. EGF-induced tyrosine phosphorylation was not abolished, although EGF-induced calcium response was completely inhibited in the presence of trapidil or suramin.

\section{Discussion}

Our study found that PDGF induced increases in $\left[\mathrm{Ca}^{2+}\right] \mathrm{i}$ of $80.0 \pm 90.4 \mathrm{nM}$ over the base level of $193 \pm 11 \mathrm{nM}$ in T98G glioma cells. The $\left[\mathrm{Ca}^{2+}\right] \mathrm{i}$ levels of quiescent glioma cells were reported to be $100-200 \mathrm{nM}^{29)}$ Our values were relatively high, but the values may vary depending on the instruments used. ${ }^{18)}$ PDGF may cause a rapid increase in $\left[\mathrm{Ca}^{2+}\right] \mathrm{i}$ by a dual mechanism: a transient increase in $\left[\mathrm{Ca}^{2+}\right] \mathrm{i}$ results from an initial release of intracellular stores and a subsequent $\mathrm{Ca}^{2+}$ influx occurs across the plasma membrane. ${ }^{10,12,29)}$ These studies were carried out using cells which express abundant PDGF receptors on the cell surface, and the responses may be dependent on the type of cells. We found that the PDGF-induced calcium response was abolished by removal of extracellular $\mathrm{Ca}^{2+}$ with EGTA, but not

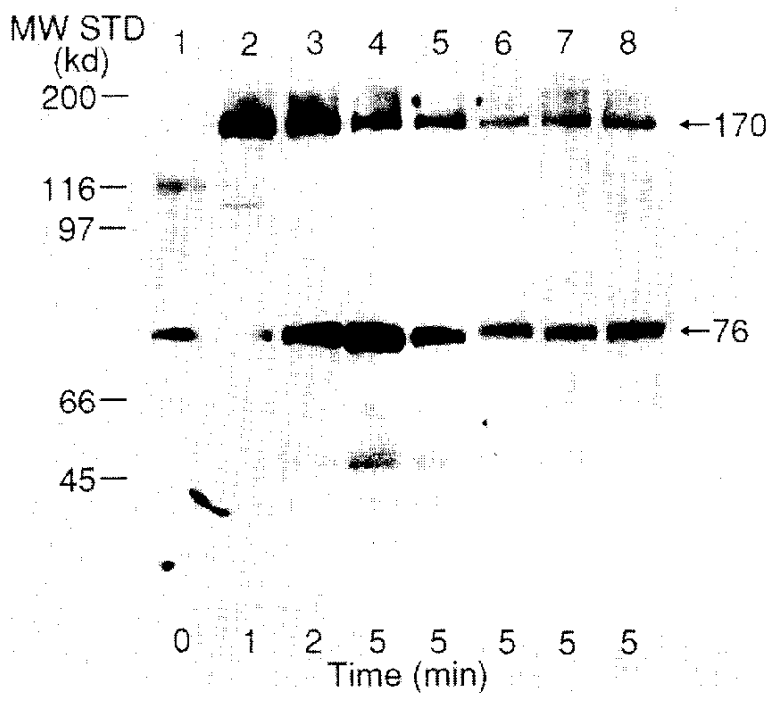

Fig. 5 Effects of trapidil and suramin on EGF-induced protein tyrosine phosphorylation. Cell proteins were extracted before (lane 1), and 1 (lane 2), 2 (lane 3), and 5 minutes (lane 4) after stimulation with $100 \mathrm{ng} / \mathrm{ml}$ EGF, and 5 minutes after stimulation from cells pretreated with 50 (lane 5) and $100 \mu \mathrm{g} / \mathrm{ml}$ trapidil (lane 6) or 100 (lane 7) and $200 \mu \mathrm{g} / \mathrm{ml}$ suramin (lane 8). Arrows indicate molecular masses of protein bands calculated from the position of molecular weight standards (MW STD). Results are representative of three separate experiments.

by treatment with nicardipine in T98G glioma cells. These results suggest that the influx of extracellular $\mathrm{Ca}^{2+}$ may be the main component of the PDGF-induced increase of $\left[\mathrm{Ca}^{2+}\right] \mathrm{i}$, and that the influx is mediated by receptor-opened voltage-independent calcium channels and not by voltage-dependent channels.

Trapidil pretreatment of T98G cells completely inhibited the PDGF-induced calcium response, but not the FBS response. Pretreatment of T98G cells with trapidil also inhibited PDGF-initiated tyrosine phosphorylation of the $185 \mathrm{kd}$ protein. In addition, PDGF stimulation of trapidil-treated cells caused dephosphorylation of the $130 \mathrm{kd}$ protein, which previously contained phosphotyrosine. Characterization and identification of this protein may be the next important step to understand the actions of trapidil. Trapidil inhibited both the PDGF-initiated calcium response and tyrosine phosphorylation, supporting the concept that trapidil functions as a competitive inhibitor, binding preferentially to PDGF-receptor sites. ${ }^{23)}$ 
Trapidil is also reported to suppress the EGFstimulated proliferation of meningioma cells in vitro. ${ }^{32 y}$ Trapidil inhibited the EGF-induced calcium response but only partially decreased EGF-induced tyrosine phosphorylation of the $170 \mathrm{kd}$ protein. These results suggest that trapidil may block not only the PDGF binding to its receptor but also inhibit the voltage-independent calcium channels that might be commonly activated by both PDGF and EGF.

Suramin inhibits the receptor binding of growth factors including PDGF, EGF, fibroblast growth factor, TGF- $\beta, 2,5)$ and inactivates reverse transcriptase and deoxyribonucleic acid polymerase. ${ }^{6,19,27)}$ The effect of suramin on tyrosine phosphorylation varies depending on the type of cell studied, but inhibits $^{9,11)}$ or activates ${ }^{4,26)}$ mitogen-induced tyrosine phosphorylation. We found suramin inhibited both PDGF-induced tyrosine phosphorylation of $185 \mathrm{kd}$ protein and increase of $\left[\mathrm{Ca}^{2+}\right] \mathrm{i}$ in $\mathrm{T} 98 \mathrm{G}$ cells, indicating inhibitory action at the receptor level. This agrees with the findings that suramin forms a complex with PDGF and dissociates PDGF from its receptor. ${ }^{13)}$ Suramin similarly inhibited the EGF-induced calcium response but did not abolish tyrosine phosphorylation.

In the present study, trapidil and suramin had similar inhibitory actions on PDGF- or EGF-initiated mitogen signals at the receptor level. Both agents blocked the increase of $\left[\mathrm{Ca}^{2+}\right] \mathrm{i}$ but did not inhibit tyrosine phosphorylation in response to EGF. This indicates that multiple pathways may be involved in the inhibitory actions of the two agents. Suramin-protein complex is taken up by cells, ${ }^{7}$ and may inhibit signal transduction pathways including hydrolysis of phosphoinositides. ${ }^{14}$

Our study confirms that trapidil and suramin may be clinically useful as an anti-cancer agents, and also suggests that these agents may be useful to study the biochemical signal events leading to proliferation of glioma cells in vitro.

\section{References}

1) Bai LY, Miyazaki M, Namba M: Effects of suramin on cell proliferation of various types of human malignant cells. Gan To Kagaku Ryoho 18: 387-391, 1991 (in Japanese)

2) Betsholtz C, Johnsson A, Heldin $\mathbf{C H}$, Westermark B: Efficient reversion of simian sarcoma virustransformation and inhibition of growth factor-induced mitogenesis by suramin. Proc Natl Acad Sci USA 83: 6440-6444, 1986

3) Cantley LC, Auger KR, Carpenter C, Duckworth B, Graziani A, Kapeller R, Soltoff S: Oncogenes and signal transduction. Cell 64: 281-302, 1991
4) Cardinali M, Sartor O, Robbins KC: Suramin, an experimental chemotherapeutic drug, activates the receptor for epidermal growth factor and promotes growth of certain malignant cells. $J$ Clin Invest 89 : 1242-1247, 1992

5) Coffey RJ, Leof EB, Shipley GD, Moses HL: Suramin inhibition of growth factor receptor binding and mitogenicity in AKR-2B cells. J Cell Physiol 132: 143-148, 1987

6) De Clercq E: Suramin: A potent inhibitor of the reverse transcriptase of RNA tumor viruses. Cancer Lett 8: 9-22, 1979

7) De Duve C, De Barsy T, Poole B, Trouet A, Tulkens P, Van Hoof F: Lysosomotrophic agents. Biochem Pharmacol 23: 2495-2531, 1974

8) Fantini J, Guo XJ, Marvaldi J, Rougoun G: Suramin inhibits proliferation of rat glioma cells and alters $\mathrm{N}-$ CAM cell surface expression. Int $J$ Cancer 45: 554561,1990

9) Fleming TP, Matsui T, Heidaran MA, Molloy CJ, Artrip J, Aaronson SA: Demonstration of an activated platelet-derived growth factor autocrine pathway and its role in human tumor cell proliferation in vitro. Oncogene 7: 1355-1359, 1992

10) Fukuo K, Morimoto S, Kaji K, Koh E, Hironaka T, Morita R, Kim S, Onishi T: Association of increased intracellular free $\mathrm{Ca}^{2+}$ by platelet-derived growth factor with mitogenesis but not with proteoglycan synthesis in chondrocytes: Effect of suramin. Cell Calcium 10: 29-35, 1989

11) Ghosh J, Miller RA: Suramin, an experimental chemotherapeutic drug, irreversibly blocks $\mathrm{T}$ cell CD45-protein tyrosine phosphatase in vitro. Biochem Biophys Res Commun 194: 36-44, 1993

12) Gonzalez FA, Heppel LA, Gross DJ, Webb WW, Parries G: The rapid desensitization of receptors for platelet derived growth factor, bradykinin and ATP: Studies on individual cells using quantitative digital video fluorescence microscopy. Biochem Biophys Res Commun 151: 1205-1212, 1988

13) Hosang M: Suramin binds to platelet-derived growth factor and inhibits its biological activity. $J$ Cell Biochem 29: 265-273, 1985

14) Kopp R, Pfeiffer A: Suramin alters phosphoinositide synthesis and inhibits growth factor receptor binding in HT-29 cells. Cancer Res 50: 6490-6496, 1990

15) Kruskal BA, Shak S, Maxfield FR: Spreading of human neutrophils is immediately preceded by a large increase in cytoplasmic free calcium concentration. Proc Natl Acad Sci USA 83: 2919, 1986

16) Kuratsu J, Estes JE, Yokota S, Mahaley MS Jr, Gillespie GY: Growth factors derived from a human malignant glioma cell line, U-251 MG. $J$ Neurooncol 7: 225-235, 1989

17) Kuratsu J, Ushio $Y$ : Antiproliferative effect of trapidil, a platelet-derived growth factor antagonist, on a glioma cell line in vitro. $J$ Neurosurg 73: 436440, 1990

18) Mazorow DL, Millar DB: Quin-2 and fura-2 measure 
calcium differently. Anal Biochem 186: 28-30, 1990

19) Mitsuya $H$, Popovic $M$, Yarchoan R, Matsushita $S$, Gallo RC, Broder S: Suramin protection of T cells in vitro against infectivity and cytopathic effect of HTLV-III. Science 226: 172-174, 1984

20) Nishibe S, Wahl MI, Hernandez-Sotomayor SMT, Tonks NK, Rhee SG, Carpenter G: Increase of the catalytic activity of phospholipase $\mathrm{C}-\gamma 1$ by tyrosine phosphorylation. Science 250: 1253-1256, 1990

21) Nister M, Libermann TA, Betsholz $C$, Pettersson $M$, Claesson WL, Heldin $\mathrm{CH}$, Schlessinger J, Westermark B: Expression of messenger RNAs for plateletderived growth factor and transforming growth factor- $\alpha$ and their receptors in human malignant glioma cell lines. Cancer Res 48: 3910-3918, 1988

22) Ohnishi H, Kosuzume H, Yamaguchi K, Satoh M, Umehara S, Funato H, Itoh C, Suzuki K, Kitamura Y, Suzuki Y, Itoh R: Pharmacological properties of trapidil: Comparison with other coronary vasodilators. Nippon Yakurigaku Zasshi 76: 495503, 1980 (in Japanese)

23) Ohnishi H, Yamaguchi $K$, Shimada S, Suzuki $Y$, Kumagai A: A new approach to the treatment of atherosclerosis and trapidil as an antagonist to platelet-derived growth factor. Life Sci 28: 16411646,1981

24) Pollack IF, Randall MS, Kristofik MP, Kelly RH, Selker RG, Vertosick FT Jr: Response of malignant glioma cell lines to epidermal growth factor and platelet-derived growth factor in a serum-free medium. I Neurosurg 73: 106-112, 1990

25) Pollack IF, Randall MS, Kristofik MP, Kelly RH, Selker RG, Vertosick FT Jr: Response of low-passage human malignant gliomas in vitro to stimulation and selective inhibition of growth factor-mediated pathways. $J$ Neurosurg 75: 284-293, 1991

26) Sartor O, McLellan CA, Myers CE, Borner MM:
Suramin rapidly alters cellular tyrosine phosphorylation in prostate cancer cell lines. J Clin Invest 90: $2166-2174,1990$

27) Spigelman Z, Dowers A, Kennedy S: Antiproliferative effects of suramin on lymphoid cells. Cancer Res 47: 4694-4698, 1987

28) Stein GH: T98G: An anchorage-independent human tumor cell line that exhibits stationary phase G1 arrest in vitro. $J$ Cell Physiol 99: 43-54, 1979

29) Szollosi J, Feuerstein BG, Vereb G, Pershadsingh HA, Marton LJ: Calcium channels in PDGFstimulated A 172 cells open after intracellular calcium release and are not voltage-dependent. Cell Calcium 12: 477-491, 1991

30) Tada $M$, Aida $T$, Hosokawa $M$, Kobayashi $H$, Sawamura Y, Abe $\mathrm{H}$ : Antiproliferative effect of trapidil on PDGF-associated growth of human glioma cell lines in vitro. Neurol Med Chir (Tokyo) 31: 313-317, 1991

31) Tanihara $H$, Ohuchi $T$, Yoshimura $N$, Negishi $M$, Ito $\mathrm{S}$ : Heterogeneous response in calcium signaling by adrenergic and cholinergic stimulation in culture bovine trabecular cells. Exp Eye Res 52: 393, 1991

32) Todo $T$, Adams EF, Fahlbusch R: Inhibitory effect of trapidil on human meningioma cell proliferation via interruption of autocrine growth stimulation. $J$ Neurosurg 78: 463-469, 1993

33) Westphal M, Ackermann E, Hoppe J, Herrmann HD: Receptors for platelet derived growth factor in human glioma cell lines and influence of suramin on cell proliferation. J Neurooncol 11: 207-213, 1991

Address reprint requests to: K. Bando, M.D., Department of Neurosurgery, Oita Nakamura Hospital, 3-2-43 Ote-machi, Oita 870, Japan. 